\title{
Do Orthodontists and Orthodontic Residents Perceive that Work-Life Balance and Work-Family Conflicts Affect Their Organizational Commitment?
}

\author{
Tolulase Abosede Yemitan ${ }^{1, \odot}$ Tope Emmanuel Adeyemi² \\ ${ }^{1}$ Department of Child Dental Health, Faculty of Dentistry, Lagos \\ State University College of Medicine, Ikeja, Lagos, Nigeria \\ ${ }^{2}$ Department of Child Dental Health, Faculty of Dentistry, Bayero \\ University/Aminu Kano Teaching Hospital, Kano, Nigeria \\ Address for correspondence Tolulase Abosede Yemitan, \\ BDS, FWACS, Department of Child Dental Health, Faculty of \\ Dentistry, Lagos State University College of Medicine, Ikeja, \\ Lagos 00176-0000, Nigeria (e-mail: tolulaseyemitan@yahoo.com).
}

Eur Dent Res Biomater J 2021;2:6-11.

\begin{abstract}
Keywords

- health careers

- family issues

- gender

- overcoming job stress

- orthodontics

Objectives Two of lives' most important domains may be in conflict with each other. This study investigated the association between perceived work-life balance (WLB), work interference with family (WIF), family interference with work (FIW), and organizational commitment (OC) of Nigerian orthodontists and orthodontic residents.

Materials and Methods Consultant orthodontists $(n=37)$ as well as orthodontics residents $(n=33)$ responded to an electronic questionnaire.

Statistical Analysis Multivariate analysis of variance assessed significant differences among demographic and career features on WLB, WIF, and FIW. Spearman's correlation coefficient and then multiple regression analysis examined relationships among perception of WLB, WIF, FIW, and OC.

Results Perceived WLB and WIF had statistically significant negative correlation with OC among Nigerian orthodontic practitioners. However, the study finds a positive, but not statistically significant correlation of perception of FIW and OC.

Conclusion Perceived WLB and WIF are significant contributors to levels of OC among Nigerian orthodontists and orthodontic residents. Multiple regression analysis identified a model that includes perceived WLB, WIF, and FIW that accounts for $16.7 \%$ of the variation in $\mathrm{OC}$.
\end{abstract}

\section{Introduction}

Although several studies have reported high job satisfaction among orthodontists, ${ }^{1-3}$ career satisfaction, and balance of work and other facets of life may be negatively impacted by various constraining influences.

The desire to continue the membership of an organization indicate organizational commitment (OC). Commitment to work in an organization has been described as either affective, continuance, or normative. Affective commitment was described as when a worker is emotionally attached to an organization. When a worker stays with an organization based on a perceived price of leaving, it was described as continuance commitment while the moral commitment of a worker to stay with an organization was called normative commitment. ${ }^{4}$

Work-life balance suggests the presence of satisfaction and functionality at work and at home with minimum conflicts between both roles. ${ }^{5} \mathrm{~A}$ conflict between work and domestic spheres can arise. ${ }^{6}$ This may either show as WIF, with difficulty to function in a family domain role because of
DOI https://doi.org/ 10.1055/s-0041-1727089 (c) 2021. European Dental Research and Biomaterials Journal.

This is an open access article published by Thieme under the terms of the Creative Commons Attribution-NonDerivative-NonCommercial-License, permitting copying and reproduction so long as the original work is given appropriate credit. Contents may not be used for commercial purposes, or adapted, remixed, transformed or built upon. (https://creativecommons.org/licenses/by-nc-nd/4.0/).

Thieme Medical and Scientific Publishers Pvt. Ltd. A-12, 2nd Floor, Sector 2, Noida-201301 UP, India 
time devoted to a work role, ${ }^{7}$ or present as FIW, with interference between household tasks and work domain. ${ }^{8}$

In determining relationships between WLB and OC, it had been shown that commitment to work depends on the capacity to balance work and domestic activities, job satisfaction, and satisfaction with conditions of service. ${ }^{9}$

Although work-family conflicts were reportedly related to gender; however, with increased skill, gender notwithstanding, work-family conflicts declined. This was attributed to accommodations made by work-oriented people to reduce conflicts with career duties while family-oriented workers make accommodations to reduce conflicts with family responsibilities. ${ }^{10}$

Despite orthodontics' relative longevity as a dental specialty, research into orthodontic specialists' and trainees' individual, work, and practice characteristics has been scarce, making this aspect of the orthodontic career largely subjective in evidence. This dearth of methodical data can create barriers to detecting and understanding contributing factors to orthodontist's individual and professional achievement. Such data could be useful in the selection of new associates as well as assist in the retention of current practitioners.

This study investigated how perceived WLB, WIF, FIW, and $\mathrm{OC}$ of Nigerian orthodontists and orthodontic residents interrelate.

\section{Materials and Methods}

\section{Ethical Consideration}

Institutional review board approval was obtained. A consent letter was e-mailed to each study participant.

\section{Participants}

The target population for this study was orthodontic residents in training and orthodontists working in Nigeria. A current list of all orthodontists and orthodontic residents in Nigeria was obtained from the Nigerian Association of Orthodontists (NAO) database. Individual residency programs were contacted to verify the list of all orthodontic residents.

\section{Sampling Method}

This was a prospective and questionnaire-based study. A purposive sampling technique was used.

\section{Data Collection}

An electronic questionnaire was distributed by using Google Forms to Nigeria-based members of NAO, with three follow-up reminders sent at 7-day intervals. Those working outside Nigeria, retired orthodontists and nonspecialists were excluded. There were approximately 97 orthodontists and orthodontic residents practicing in Nigeria who met the criteria. The first posting resulted in 37 responses. The first additional emailing to nonrespondents added 18 questionnaires. The second additional posting returned six responses. The third and last reminder produced nine responses. A 72.2\% response rate was attained. Nonresponse error was handled to guarantee external validity by comparing initial and late responders. ${ }^{11}$

\section{Research Measures}

The questionnaire was piloted with four orthodontists and four orthodontic residents prior to final distribution to verify validity and ease of completion. A final version was developed after modifications were made. Section one had demographic information such as gender, age, marital status, and professional status. Section two had a WLB scale ${ }^{12}$ with statements related to WLB (-Table 2). Higher mean scores of the WLB scale represent increased perception of achievement and belief of WLB. ${ }^{12}$

Sections three and four included scales for the perception of WIF and of FIW respectively ( - Table 2 ), measured using eight statements. ${ }^{8}$ High scores on each measure represents high perception of interference.

The degree of $\mathrm{OC}$ is measured by using a portion of commitment index in section five ( - Table 2 ).${ }^{13}$ It has 11 statements rated for respondent's belief on OC.

\section{Data Analysis}

Statistical evaluation was done by using the Statistical Package for the Social Sciences (SPSS, version 22.0) software. Assessment of internal consistency using Cronbach's $\alpha$ showed internal reliability of 0.67 for WLB scale, while WIF and FIW scales had internal reliability of 0.82 and 0.87 , respectively. Comparison of early and late responders using $t$-tests showed no significant difference with the mean difference range of -0.80 to 0.68 . Multivariate analysis of variance tested variances among demographic and career features for WLB, WIF, and FIW. Spearman's correlation coefficient and multiple regression analysis tested for relationships among perception of WLB, WIF, FIW, and OC. A level of 0.05 significance was set.

\section{Results}

The demographics and career features of study participants are presented in - Table $\mathbf{1}$.

The relationship between sociodemographic characteristics and perceptions of WLB, WIF, and FIW (- Table 3) showed a statistically significant relations between gender and work-family conflicts, but revealed no significant relations between gender and WLB. Age was found to have statistically significant relationship with WLB and FIW. Marital status had a statistically significant relationship with WIF, while ethnicity revealed a statistically significant association with WLB and WIF. A statistically significant association between geographical location within the country and perception of WLB, WIF, and FIW was found ( $p<0.05$ ).

The relationship between career characteristics and perceptions of WLB, WIF, and FIW, presented in - Table 4, showed a statistically significant relationship between professional status; number of years since graduation as a dentist and type of orthodontic practice; and perception of WLB, WIF, and FIW ( $p<0.05)$.

Perception of WLB and WIF correlated statistically significantly to OC, $p<0.05$ (-Table 5). Regression analysis (-Table 5) showed that the perception of WLB, WIF, and FIW explains $16.7 \%$ of the variability of OC, $\mathrm{F}(3,66)=4.407$, $p<0.01, \mathrm{R}^{2}=0.167$. 
Table 1 Sociodemographics and career characteristics of respondents

\begin{tabular}{|c|c|c|}
\hline Variable & $n$ & $\%$ \\
\hline \multicolumn{3}{|l|}{ Gender } \\
\hline Male & 21 & 30 \\
\hline Female & 49 & 70 \\
\hline Total & 70 & 100 \\
\hline \multicolumn{3}{|l|}{ Age group (y) } \\
\hline $21-30$ & 13 & 18.6 \\
\hline $31-40$ & 19 & 27.1 \\
\hline $41-50$ & 23 & 32.9 \\
\hline $51-60$ & 11 & 15.7 \\
\hline $61-70$ & 4 & 5.7 \\
\hline Total & 70 & 100 \\
\hline \multicolumn{3}{|l|}{ Marital status } \\
\hline Single & 4 & 5.7 \\
\hline Married & 64 & 91.4 \\
\hline Widow/widower & 2 & 2.9 \\
\hline Total & 70 & 100 \\
\hline \multicolumn{3}{|l|}{ Ethnicity } \\
\hline Yoruba & 52 & 74.3 \\
\hline Igbo & 11 & 15.7 \\
\hline Other & 7 & 10 \\
\hline Total & 70 & 100 \\
\hline \multicolumn{3}{|l|}{ Geographical location } \\
\hline North-West & 3 & 4.3 \\
\hline North-Central & 3 & 4.3 \\
\hline South-South & 10 & 14.3 \\
\hline South-East & 1 & 1.4 \\
\hline South-West & 53 & 75.7 \\
\hline Total & 70 & 100 \\
\hline \multicolumn{3}{|l|}{ Career status } \\
\hline Consultant/specialist & 37 & 52.9 \\
\hline Senior registrar & 20 & 28.6 \\
\hline Junior registrar & 13 & 18.6 \\
\hline Total & 70 & 100 \\
\hline \multicolumn{3}{|c|}{ Number of years post-BDS graduation } \\
\hline $0-10$ & 12 & 17.1 \\
\hline $11-20$ & 37 & 52.9 \\
\hline $21-30$ & 13 & 18.6 \\
\hline $31-40$ & 8 & 11.4 \\
\hline Total & 70 & 100 \\
\hline \multicolumn{3}{|l|}{ Type of practice } \\
\hline Government & 42 & 60 \\
\hline Private & 8 & 11.4 \\
\hline Both & 20 & 28.6 \\
\hline Total & 70 & 100 \\
\hline
\end{tabular}

Abbreviation: BDS, Bachelor of Dental Surgery.

\section{Discussion}

The findings in this study revealed statistically significant relationships between respondents' demographic/career characteristics and their perception of WLB, WIF, and FIW ( - Tables 3 and $\mathbf{4}$ ). Gender showed a statistically significant relationship with WIF and FIW (-Table 3). Previous studies found that women with household tasks and childcare responsibilities engaging in employments to maintain their skills and source of income contribute to work-family conflicts. ${ }^{14,15}$ It was also suggested that because men characteristically sacrifice time at home for work activities, while women sacrifice time at work for home obligations, WIF happened more than FIW among males. ${ }^{16-18}$

The present study found that marital status of orthodontists and orthodontic residents has a statistically significant relationship with perception of WIF ( - Table 3 ), in agreement with previous study which found that married workers gave more importance to families compared with work. ${ }^{19}$

In agreement with a study that reported age as an indicator of work-life conflict, ${ }^{20}$ this present study found that age had a statistically significant relationship with WLB and FIW ( - Table 3 ). This may be related to lower workload enjoyed by older employees, which may lead to greater success with WLB and reduced conflict between work and home responsibilities. ${ }^{21}$

A statistically significant relationship between career characteristics and perceived WLB, WIF, and FIW ( - Table 4 ) was found in our study, in agreement with previous study which found that individuals in high-status occupation categories reported greater interference than those in low-status occupation categories. ${ }^{22}$ It was suggested that higher demands placed on higher occupation status may require taking work home.

Our results found perceived WLB had a statistically significant and negative correlation with OC (-Table 5), which is however weak with $32.4 \%$ correlation. The weak negative relationship between WLB and OC could imply that other influences, for instance, quality of life as orthodontists, the practice involved in orthodontics, level of patient interactions, relationships with other staff and colleagues, and the respect derived from being an orthodontist may influence orthodontists' job commitment. The present study, however, differs from previous studies that observed a positive significant association between WLB and OC..$^{23-25}$ It was suggested that occupations with busy work calendar often face a struggle to maintain a good WLB, with direct impact on OC.

The link between WLB and OC was described by a theory, ${ }^{26}$ which suggests that existing WLB policies encourage workers contribution in an organization in a way that the workers obliged to apply hard work in exchange for such rewards. Therefore, an individual whose personal life constrained by the working environment in an organization is more likely to leave the organization to work where it is possible to balance work and family activities. ${ }^{27}$

The results from the present study showed that perceived WIF had a statistically significant and negative relationship 
Table 2 The mean and standard deviation (SD) for statements related to each scale

\begin{tabular}{|c|c|c|}
\hline Work life balance scale & Mean & SD \\
\hline Allows time balance between work and family & 5.66 & 1.58 \\
\hline Work demands not compromising family tasks & 5.50 & 1.77 \\
\hline Allows fulfilling personal life and adequate work duties & 6.34 & 0.70 \\
\hline Allows successful orthodontic career & 5.77 & 1.58 \\
\hline Helps retention in the orthodontic profession & 5.19 & 1.49 \\
\hline Mean & 5.69 & 0.97 \\
\hline \multicolumn{3}{|l|}{ Work interference with family scale } \\
\hline Too tired after work to do things I love to do & 5.54 & 1.35 \\
\hline Work load inhibits my personal interests & 4.80 & 1.59 \\
\hline Family/friends disapprove preoccupation with work while at home & 4.01 & 1.77 \\
\hline Work takes up time that I desire to spend with family/friends & 4.80 & 1.65 \\
\hline Mean & 4.79 & 1.28 \\
\hline \multicolumn{3}{|l|}{ Family interference with work scale } \\
\hline Frequently tired at work because of home responsibilities & 2.69 & 1.39 \\
\hline Personal responsibilities take away from my work & 2.59 & 1.62 \\
\hline Friends dislike my preoccupation with personal matters while at work & 2.01 & 1.10 \\
\hline Personal matters uses time that I desire to spend on work & 2.10 & 1.30 \\
\hline Mean & 2.35 & 1.16 \\
\hline \multicolumn{3}{|l|}{ Organizational commitment scale } \\
\hline I may perhaps go into a different occupation & 2.41 & 1.72 \\
\hline I foresee being in this profession for several years & 6.07 & 1.18 \\
\hline My selected career is a good choice & 2.11 & 1.53 \\
\hline I am indecisive about the choice of this profession & 5.77 & 1.21 \\
\hline I would still practice this occupation despite not needing money & 3.29 & 1.80 \\
\hline I am occasionally discontented with this profession & 3.29 & 1.80 \\
\hline I do not plan to give up my profession since I love it & 5.09 & 1.73 \\
\hline I was educated for another occupation & 1.59 & 1.11 \\
\hline My profession is ideal for what I want to do in life & 5.79 & 1.02 \\
\hline I wish I am in another profession & 2.13 & 1.44 \\
\hline I am disenchanted with this occupation & 1.57 & 0.96 \\
\hline Mean & 3.56 & 0.49 \\
\hline
\end{tabular}

Abbreviation: SD, standard deviation.

with OC. This study corroborates previous studies that reported WIF negatively correlates with affective commitment. ${ }^{28-30}$ It however contradicts studies that reported WIF positively relates with continuance commitment in which the cost associated with leaving an organization influences commitment. ${ }^{31}$

The present study found a positive association between perception of FIW and OC, which was however not statistically significant. Although there have been reports suggesting negative relations between FIW and affective commitment; ${ }^{29}$ others found no association. ${ }^{31,32}$

Cinamon's ${ }^{33}$ hypothesis which stated that work impacts family life more negatively than family impacts work life was corroborated by the present study. A plausible explanation for this difference may be obtained from the boundary theory which proposed that the domains of WIF and FIW can be separated to create and maintain a mental boundary. ${ }^{34,35}$

\section{Implications}

Results from this study shows the need for the health industry to review the working conditions of orthodontists and orthodontic residents and to plan better human resource policies that are more family friendly knowing that orthodontists and orthodontic residents may experience family-work conflicts that can lead to reduced OC. There is a need for family-friendly policies that allows more flexibility so that orthodontists are able to arrange time for their family, hence reducing the interference brought to work. Human resources department can also plan for onsite facilities such as childcare nurseries to help orthodontists play their family role.

\section{Limitations}

Limitations that characterized the present study design include the study's inability to establish causal relationship. This is attributed to use of cross-sectional data which 
Table 3 The relationship between sociodemographic characteristics and perceptions of work life balance, work interference with family, and family interference with work

\begin{tabular}{|c|c|c|c|c|c|}
\hline Variable & $n$ & Mean & SD & $F$ & $p$-Value \\
\hline \multicolumn{6}{|l|}{$\begin{array}{l}\text { Perception of } \\
\text { work life balance }\end{array}$} \\
\hline Gender & 70 & 1.70 & 0.46 & 1.616 & 0.168 \\
\hline Age group & 70 & 2.63 & 1.13 & 4.476 & $0.000^{c}$ \\
\hline Marital status & 70 & 2.00 & 0.42 & 1.358 & 0.207 \\
\hline Ethnicity & 70 & 1.46 & 0.93 & 2.285 & $0.017^{\mathrm{a}}$ \\
\hline $\begin{array}{l}\text { Geographical } \\
\text { location }\end{array}$ & 70 & 5.36 & 1.29 & 1.795 & $0.021^{\mathrm{a}}$ \\
\hline \multicolumn{6}{|l|}{$\begin{array}{l}\text { Perception of } \\
\text { work interference } \\
\text { with family }\end{array}$} \\
\hline Gender & 70 & 1.70 & 0.46 & 7.657 & $0.000^{c}$ \\
\hline Age group & 70 & 2.63 & 1.13 & 1.547 & 0.104 \\
\hline Marital status & 70 & 2.00 & 0.42 & 4.806 & $0.000^{c}$ \\
\hline Ethnicity & 70 & 1.46 & 0.93 & 2.675 & $0.011^{\mathrm{a}}$ \\
\hline $\begin{array}{l}\text { Geographical } \\
\text { location }\end{array}$ & 70 & 5.36 & 1.29 & 1.838 & $0.029^{\mathrm{a}}$ \\
\hline \multicolumn{6}{|l|}{$\begin{array}{l}\text { Perception of } \\
\text { family interfer- } \\
\text { ence with work }\end{array}$} \\
\hline Gender & 70 & 1.70 & 0.46 & 2.740 & $0.040^{\mathrm{a}}$ \\
\hline Age group & 70 & 2.63 & 1.13 & 1.956 & $0.032^{\mathrm{a}}$ \\
\hline Marital status & 70 & 2.00 & 0.42 & 1.817 & 0.083 \\
\hline Ethnicity & 70 & 1.46 & 0.93 & 0.708 & 0.684 \\
\hline $\begin{array}{l}\text { Geographical } \\
\text { location }\end{array}$ & 70 & 5.36 & 1.29 & 2.371 & $0.003^{b}$ \\
\hline
\end{tabular}

Abbreviation: SD, standard deviation.

aSignificant at $<0.05$ level

bSignificant at $<0.01$ level

'Significant at $<0.001$ level
Table 4 The relationship between career characteristics and perceptions of work life balance, work interference with family, and family interference with work

\begin{tabular}{|c|c|c|c|c|c|}
\hline Variable & $n$ & Mean & SD & $F$ & $p$-Value \\
\hline \multicolumn{6}{|l|}{$\begin{array}{l}\text { Perception of work } \\
\text { life balance }\end{array}$} \\
\hline Career status & 70 & 1.66 & 0.78 & 3.916 & $0.000^{c}$ \\
\hline $\begin{array}{l}\text { Post-BDS gradua- } \\
\text { tion (years) }\end{array}$ & 70 & 2.24 & 0.88 & 2.836 & $0.001^{b}$ \\
\hline Type of practice & 70 & 1.69 & 0.89 & 4.135 & $0.000^{c}$ \\
\hline \multicolumn{6}{|l|}{$\begin{array}{l}\text { Perception of work } \\
\text { interference with } \\
\text { family }\end{array}$} \\
\hline Career status & 70 & 1.66 & 0.78 & 3.783 & $0.010^{\mathrm{a}}$ \\
\hline $\begin{array}{l}\text { Post-BDS gradua- } \\
\text { tion (years) }\end{array}$ & 70 & 2.24 & 0.88 & 2.708 & $0.003^{b}$ \\
\hline Type of practice & 70 & 1.69 & 0.89 & 2.681 & $0.011^{\mathrm{a}}$ \\
\hline \multicolumn{6}{|l|}{$\begin{array}{l}\text { Perception of family } \\
\text { interference with } \\
\text { work }\end{array}$} \\
\hline Career status & 70 & 1.66 & 0.78 & 2.649 & $0.045^{\mathrm{a}}$ \\
\hline $\begin{array}{l}\text { Post-BDS gradua- } \\
\text { tion (years) }\end{array}$ & 70 & 2.24 & 0.88 & 2.075 & $0.022^{\mathrm{a}}$ \\
\hline Type of practice & 70 & 1.69 & 0.89 & 2.611 & $0.013^{\mathrm{a}}$ \\
\hline
\end{tabular}

Abbreviations: BDS, Bachelor of Dental Surgery; SD, standard deviation. aSignificant at $<0.05$ level

bSignificant at $<0.01$ level

'Significant at $<0.001$ level

may show associations between studied variables, but cannot establish that such associations were causal. Therefore, prospective studies using in-depth interviews would allow future research to explore further and investigate the causal influences among the relationships found in this study.

The use of questionnaires to obtain data regarding self-perceptions from respondents assumes honesty and no

Table 5 Results of correlation between perception of work-life balance, perception of work interference with family, perception of family interference with work, and organizational commitment

\begin{tabular}{|l|l|l|l|l|}
\hline Variable & 1 & 2 & 3 & 4 \\
\hline Correlation & & & & \\
\hline 1. Organizational Commitment & 1 & $-0.324^{\mathrm{b}}$ & $-0.247^{\mathrm{a}}$ & 0.072 \\
\hline 2. Perceived work life balance & & 1 & 0.068 & -0.099 \\
\hline 3. Perceived work interference with family & & & 1 & $0.266^{\mathrm{a}}$ \\
\hline 4. Perceived family interference with work & & & 1 \\
\hline Regression analysis & & & \\
\hline Model & $\beta$ & SE & -0.295 & Significance \\
\hline Perceived work life balance & -0.148 & 0.057 & -0.256 & $0.011^{\mathrm{a}}$ \\
\hline Perceived work interference with family & -0.097 & 0.044 & 0.111 & $0.032^{\mathrm{a}}$ \\
\hline Perceived family interference with work & 0.047 & 0.049 & & 0.347 \\
\hline$R^{2}=0.167, \mathrm{~F}(3,66)=4.407, p<0.01$ & & & \\
\hline
\end{tabular}

Abbreviation: SE, standard error.

asignificant at $p<0.05$ level

bSignificant at $p<0.01$ level 
bias from the respondents which creates a limitation on reliability of data.

\section{Conclusion}

This study found that perceived WLB and WIF significantly contributed to the level of $\mathrm{OC}$ among Nigerian orthodontists and orthodontic residents.

Regression analysis found a model with perception of WLB, WIF, and FIW that accounts for $16.7 \%$ of the variation in OC.

\section{Note}

Institutional review board approval was obtained from the ethical review board of Aminu Kano Teaching Hospital, with approval number NHREC/28/01/2020/AKTH/EC/2874.

\section{Funding}

None.

\section{Conflict of Interest}

None declared.

\section{References}

1 Roth SF, Heo G, Varnhagen C, Glover KE, Major PW. Job satisfaction among Canadian orthodontists. Am J Orthod Dentofacial Orthop 2003;123(6):695-700

2 Bateman LE, Collins JM, Cunningham SJ. A qualitative study of work-life balance amongst specialist orthodontists in the United Kingdom. J Orthod 2016;43(4):288-299

3 Alqahtani ND, Alshehry K, Alateeq S, et al. An assessment of job satisfaction: a cross-sectional study among orthodontists of Saudi Arabia. J Orthod Sci 2018;7(1):4

4 Herscovitch L, Meyer JP. Commitment to organizational change: extension of a three-component model. J Appl Psychol 2002;87(3):474-487

5 Clark SC. Work/family border theory: a new theory of work/life balance. Hum Relat 2000;53(6):747-770

6 Carlson DS, Kacmar KM. Work-family conflict in the organization: do life role values make a difference? J Manage 2000;26(5):1031-1054

7 Weckström S. Working mothers in Finland: a cross-country comparison of work to family interference, work characteristics and satisfaction with life. Finn Yearb Popul Res 2011;46: 71-94

8 Gutek BA, Searle S, Klepa L. Rational versus gender role explanations for work-family conflict. J Appl Psychol 1991;76(4):560-568

9 Beauregard TA, Henry LC. Making the link between work-life balance practices and organisational performance. Hum Resour Manage Rev 2009;19(1):9-22

10 Cinamon RG, Rich Y. Work-family conflict among female teachers. Teach Teach Educ 2005;21(4):365-378

11 Lindner JR, Murphy TH, Briers GE. Handling nonresponse in social science research. J Agric Educ 2001;42(4):43-53

12 Chaney CA. Work-life variables influencing attrition among beginning agriscience teachers of Texas [doctoral dissertation]. Texas Tech University. Available at: https://oaktrust. library.tamu.edu/handle/1969.1/5950. Accessed 2007

13 Blau GJ, Paul A, St. John N. On developing a general index of work commitment. J Vocat Behav 1993;42(3):298-314

14 Porter S, Ayman R. Work flexibility as a mediator of the relationship between work-family conflict and intention to quit. J Manage Organ 2010;16(3):411-424
15 Warren T. Working part-time: achieving a successful 'work-life' balance? Br J Sociol 2004;55(1):99-122

16 Jennings J, McDougald M. Work-family interface experiences and coping strategies: implications for entrepreneurship research and practice. Acad Manage Rev 2007;32(3):747-760

17 Eby LT, Casper WJ, Lockwood A, Bordeaux C, Brinley A. Work and family research in IO/OB: content analysis and review of the literature (1980-2002).J Vocat Behav 2005;66(1):124-197

18 Geurts SAE, Taris TW, Kompier MAJ. Dikkers JSE, van Hooff MLM, Kinnunen UM. Work-home interaction from a work psychological perspective: development and validation of a new questionnaire, the SWING. Work Stress 2005;19(4):319-339

19 Martins LL, Eddleston KA, Veiga JF. Moderators of the relationship between work-family conflict and career satisfaction. Acad Manage J 2002;45(2):399-409

20 Wang P, Lawler J, Shi K. Work-family conflict, self-efficacy, job satisfaction, and gender: evidences from Asia. J Leadersh Organ Stud 2010;17(3):298-308

21 Tausig M, Fenwick R. Unbinding time: alternate work schedules and work-life balance. J Fam Econ Issues 2001;22(2):101-119

22 Schieman S, Milkie MA, Glavin P. When work interferes with life: work-nonwork interference and the influence of work-related demands and resources. Am Sociol Rev 2009;74(6):966-988

23 Malone EK, Issa RR. Work-life balance and organizational commitment of women in the US construction industry. J Prof Iss Eng Ed Pr 2013;139(2):87-98

24 Azeem SM, Akhtar N. The influence of work life balance and job satisfaction on organizational commitment of healthcare employees. Int J Hum Resour Stud 2014;4(2):18-24

25 Berk C, Gundogmus F. The effect of work-life balance on organizational commitment of accountants. Manage Sci 2018;13(2):137-159

26 Lambert SJ. Added benefits: the link between work life benefits and organizational citizenship behaviour. Acad Manage J 2000;43(5):801-815

27 Hatam N, Jalali MT, Askarian M, Kharazmi E. Relationship between family-work and work-family conflict with organizational commitment and desertion intention among nurses and paramedical staff at hospitals. Int J Community Based Nurs Midwifery 2016;4(2):107-118

28 Good LK, Sisler GF, Gentry JW. Antecedents of turnover intentions among retail management personnel. J Retailing 1988;64(3):295-314

29 Netemeyer RG, Boles JS, McMurrian R. Development and validation of work-family conflict and family-work conflict scales. J Appl Psychol 1996;81(4):400-410

30 Streich M, Casper WJ, Salvaggio AN. Examining couple agreement about work-family conflict. J Manag Psychol 2008;23(3):252-272

31 Casper WJ, Martin JA, Buffardi LC, Erdwins CJ. Work-family conflict, perceived organizational support, and organizational commitment among employed mothers. J Occup Health Psychol 2002;7(2):99-108

32 O'Driscoll MP, Ilgen DR, Hildreth K. Time devoted to job and off-job activities, interrole conflict, and affective experiences. J Appl Psychol 1992;77(3):272-279

33 Cinamon RG. Anticipated work-family conflict: effects of gender, self-efficacy, and family background. Career Dev Q 2006;54(3):202-215

34 Ashforth BE, Kreiner GE, Fugate M. All in a day's work: boundaries and micro role transitions. Acad Manage Rev 2000;25(3):472-491

35 Zerubavel E, The fine line: making distinctions in everyday life. New York: Free Press; 1991 